\title{
Peranan Pimpinan dalam Pengelolaan Pondok Pesantren
}

\author{
Muhamad Lutfi Nazmudin ${ }^{1 *}$, Uwoh Saepulloh $1^{1}$, Dewi Sadiah $2^{2}$ \\ ${ }^{123}$ Jurusan Manajemen Dakwah, Fakultas Dakwah dan Komunikasi, UIN Sunan Gunung Djati, \\ Bandung \\ *Email : nazmuddin.lutfi@uinsgd.ac.id
}

\begin{abstract}
ABSTRAK
Penelitian ini bertujuan untuk mengetahui proses pengambilan keputusan dan kebijakan yang diterapkan pimpinan dalam pengelolaan Pondok Pesantren AlMuhajirin Purwakarta. Metode penelitian ini menggunakan metode dengan pendekatan kualitatif. Hasil penelitian menunjukan bahwa peranan pimpinan dalam pengelolaan pondok pesantren tidak hanya berperan sebagai pemimpin saja, akan tetapi beliau juga berperan sebagai educator, manajerial, innovator, administrator, bahkan supervisor terhadap segala sesuatu yang telah ditetapkan secara efektif dan efisien dalam rangka pencapaian tujuan. Sedangkan tipe kepemimpinan beliau lebih condok pada tipe kepemimpinan demokratis dan kharismatis. Hal tersebut dapat terlihat dari cara beliau dalam mengambil keputusan yang selalu menggunakan kebersamaan dalam musyawarah untuk mencapai kata mufakat. Kemudian dalam proses penyusunan kebijakan program beliau selalu mempertimbangkan beberapa hal, diantaranya adalah tujuan utama dan fungsi keberadaan pesantren, kebutuhan santri, kondisi santri serta kondisi sarana dan prasarana yang ada di pesantren.
\end{abstract}

Kata Kunci: Pemimpin; Peranan Pemimpin; Pengelolaan Pondok Pesantren.

\section{ABSTRACT}

This study aims to determine the decision-making process and policies applied by the leadership in the management of the Al-Mubajirin Islamic Boarding School in Purwakarta. This research method uses a method with a qualitative approach. The results showed that the role of leadership in the management of boarding schools not only acted as a leader, but he also acted as educator, managerial, innovator, administrator, and even supervisor of everything that has been determined effectively and efficiently in order to achieve goals. While his type of leadership is more focused on the type of democratic and charismatic leadership. This can be seen from the way he makes decisions that always use togetherness in deliberation to reach the word 
consensus. Then in the program policy formulation process he always considered several things, including the main purpose and function of the existence of the pesantren, the needs of the santri, the condition of the students and the condition of the facilities and infrastructure in the pesantren.

Keywords: Leader; The Role of the Leader; Management of Islamic Boarding Schools.

\section{PENDAHULUAN}

Pondok pesantren merupakan suatu pendidikan Islam non formal, yang senantiasa berupaya membina kader-kader muslim dalam bidang ilmu agama Islam. Pesantren, jika disandingkan dengan lembaga pendidikan yang pernah muncul di Indonesia, merupakan sistem pendidikan tertua saat ini dan dianggap sebagai produk budaya Indonesia yang indigenous. Pendidikan ini semula merupakan pendidikan agama Islam yang dimulai sejak munculnya masyarakat Islam di Nusantara pada abad ke-13. Beberapa abad kemudian penyelenggaraan pendidikan ini semakin teratur dengan munculnya tempat-tempat pengajian ("nggon ngaji"). Bentuk ini kemudian berkembang dengan pendirian tempattempat menginap bagi para pelajar (santri), yang kemudian disebut pesantren. Meskipun bentuknya masih sangat sederhana, pada waktu itu pendidikan pesantren merupakan satu-satunya lembaga pendidikan yang terstruktur, sehingga pendidikan ini dianggap sangat bergengsi. Di lembaga inilah kaum muslimin Indonesia mendalami doktrin dasar Islam, khususnya menyangkut praktek kehidupan keagamaan.

Perkembangan pesantren yang begitu pesat juga ditengarai berkat dibukanya terusan Suez pada 1869 sehingga memungkinkan banyak pelajar Indonesia mengikuti pendidikan di Mekkah. Sepulangnya ke kampung halaman, para pelajar yang mendapat gelar "haji" ini mengembangkan pendidikan agama di tanah air yang bentuk kelembagaannya kemudian disebut "pesantren" atau "pondok pesantren".

Pada masa-masa awal, pesantren sudah memiliki tingkatan yang berbedabeda. Tingkatan pesantren yang paling sederhana hanya mengajarakan cara membaca huruf Arab dan Al-Qur'an. Sementara, pesantren yang agak tinggi adalah pesantren yang mengajarkan berbagai kitab fiqh, ilmu akidah, dan kadangkadang amalan sufi, di samping tat bahasa Arab (Nahwu Sharf). Secara umum, tradisi intelektual pesantren baik sekarang maupun waktu itu ditentukan tiga serangkai mata pelajaran yang terdiri dari fiqh menurut Madzhab Syafi'i, akidah menurut Madzhab Asy'ari, dan amalan-amalan sufi dari karya-karya Imam alGhazali (Schrorff, 1985: 21).

Secara umum pesantren tetap memiliki fungsi-fungsi sebagai: (1) lembaga pendidikan yang melakukan transfer ilmu-ilmu agam (tafaqquh $f i$ aldin) dan nilainilai Islam (Islamic values), (2) lembaga keagamaan yang melakukan kontrol sosial (social control), dan (3) lembaga keagamaan yang melakukan rekayasa sosial (social 
engineering) (Masyhud, 2005: 20).

Mempertimbangkan proses perubahan yang terjadi di pesantren, tampak bahwa hingga dewasa ini lembaga tersebut telah memberi kontribusi penting dalam penyelenggaraan pendidikan nasional. Keberadaan pesantren sebagai lembaga pendidikan, baik yang masih mempertahankan sistem pendidikan tradisionalnya maupun yang sudah mengalami perubahan, memiliki pengaruh besar dalam kehidupan masyarakat Indonesia. Dari waktu ke waktu, pesantren semakin tumbuh dan berkembang kuantitas maupun kualitasnya. Tidak sedikit dari masyarakat yang masih menaruh perhatian besar terhadap pesantren sebagai pendidikan alternatif. Terlebih lagi dengan berbagai inovasi sistem pendidikan yang dikembangkan pesantren dengan mengadopsi corak pendidikan umum, menjadikan pesantren semakin kompetitif untuk menawarkan pendidikan ke khalayak masyarakat. Meski sudah melakukan berbagai inovasi pendidikan, sampai saat ini pendidikan pesantren tidak kehilangan karakteristiknya yang unik yang membedakan dirinya dengan model pendidikan umum yang diformulasikan dalam bentuk sekolahan.

Pimpinan mempunyai kedudukan yang penting disetiap organisasi tanpa pemimpin yang baik, organisasi tidak dapat mencapai sasarannya. Pemimpin yang baik menjadi motor utama yang menggerakkan roda suatu organisasi, apakah itu dalam islam ataupun diluar islam.

Keberhasilan suatu organisasi atau lembaga-lembaga tertentu tercetak pada manajemen organisasi atau lembaga itu sendiri. Sedangkan inti dari suatu manajemen terletak pada kemampuan leader (pimpinan) manusia-manusia pengelolanya. Karena manajemen sebagai inti organisasi memiliki peranan apa yang dilakukan ke arah mana yang akan dituju oleh organisasi tersebut.

Dengan demikian, dengan adanya dari sekelompok yang diberi kedudukan tertentu dan diharapkan dapat bertindak sesuai dengan kedudukannya. Seorang pemimpin adalah juga seorang dalam kumpulan yang diharapkan menggunkan pengaruhnya dalam mewujudkan dan mencapai tujuan kelompok. Pemimpin yang jujur adalah seorang yang memimpin dan bukan seorang yang menggunkan kedudukan untuk memimpin. Pimpinan adalah bagian dari kepribadian Islam.

Dalam perkembangan sekarang ini, banyak pondok pesantren yang mempromosikan sebagai pondok pesantren modern, sebagai satu langkah untuk mengimbangi berbagai perubahan yang terjadi ditengah-tengah realitas sosial. Tetapi tentunya tidak sedikit pula pesantren yang tetap mempertahankan tradisi lama sebagai sebuah kultur yang sudah diwariskan turun-temurun.

Pondok pesantren Al-Muhajirin merupakan salah satu dari sekian banyaknya pondok pesantren yang ada sekarang ini. Sebagai sebuah lembaga pendidikan Islam yang berbeda ditengah-tengah masyarakat yang sangat antusias 
terhadap perubahan, maka tentunya Pondok Pesantren Al-Muhajirin tidak lepas dari berbagai hal yang merupakan dampak dari adanya arus globalisasi. Walaupun secara geografis Pondok Pesantren ini ada didaerah perkotaan, yang notabene mendapatakan informasi sangat mudah, tetapi asimilasi dan akulturasi kebudayaan tidak bisa dipungkiri.

Disamping kemajuan pondok pesantren, peranan pimpinan dalam kemajuan pondok pesantren ini begitu sangat berperan sekali, berperan dalam berbagai hal. Baik hal yang bersifat ekstern ataupun hal yang bersifat intern. Karena pimpinan adalah suatu pusat dimana bisa menjadikan pondok pesantren yang maju atau tidaknya, yang pastinya tidak hanya pimpinan saja yang memegang atau mengurus semuanya, karena dimana ada pimpinan, disitu pasti ada bawahan atau staf-stafnya. Sehingga bisa mewujudkan pondok pesantren yang maju. Karena didukung atau dibantu oleh stafnya (ustadz dan ustadzah, dan pengurus).

Dalam kondisi seperti ini, pimpinan Pondok Pesantren menyadari sepenuhnya, bahwa permasalahan akan muncul disekitar lembaga pendidikan yang dipimpinnya. Diantaranya yaitu, dari permasalahan yang telah berkembang, bahwa Pondok Pesantren merupakan sebagai suatu lembaga pendidikan yang terlalu berpikir ortodok, hanya mempelajari kitab-kitab klasik. Sehingga hal tersebut tidak mampu memunculkan suatu pengembangan pola pikir yang maju bagi peserta didiknya, yang dikhawatirkan sebuah kestatisan hidup yang tidak lagi memiliki nilai-nilai kompotitif.

Selain itu dengan sarana dan prasaran yang tidak menunjang ditinjau dari berbagai aspek, tentunya tidak akan menumbuhkan suatu motivasi untuk mempelajari atau memperdalam ilmu-ilmu keagamaan dilembaga tersebut. Bahkan lebih cenderung untuk masuk pada dunia pendidikan yang hanya menjadikan muatan-muatan keagamaan sebagai sebuah formalisasi serta cenderung kearah sekuler. Karena mereka merasa bahwa saran dan prasarana yang ada disana cukup memadai dengan sistem pendidikan dan pengajaran yang (dianggap) sangat menunjang terhadap upaya untuk mencapai sebuah keberhasilan hidup.

Oleh karena itu, untuk mengantisipasi dampak negatif dari berbagai perubahan yang ada, sekaligus untuk menjaga dan mengoptimalisasikan peran dan fungsi dalam kapasitasnya sebagai sebuah Pondok Pesantren, maka tentunya pimpinan Pondok Pesantren memiliki langkah-langkah sebagai sebuah kebijakan dan strategi yang ditempuhnya. Baik yang berorientasi pada peningkatan kemampuan peserta didik atau santri, maupun yang berorientasi pada pembenahan serta optimalisasi berbagai sarana dan prasarana yang dibutuhkan. 


\section{LANDASAN TEORITIS}

Teori yang akan dijadikan landasan dalam penelitian ini adalah teori peranan, teori manajemen dan teori kepemimpinan. Peranan (role) merupakan proses dinamis kedudukan (status). Apabila seseorang melaksanakan hak dan kewajiban sesuai dengan kedudukannya, dia menjalankan suatu peranan. Perbedaan antara kedudukan dengan peranan adalah untuk kepentingan ilmu pengetahuan. Keduanya tidak dapat dipisah-pisahkan karena yang satu tergantung pada yang lain dan sebaliknya (Soekanto, 2009: 212-213).

Pera mengasumsikan bahwa ketika seseorang menempati suatu posisi social tertentu perilakunya akan ditentukan oleh apa yang diharapkan ketika seseorang berada pada posisi tersebut dari pada karakteristik yang ada pada diri mereka dan peran adalah panduan sifatdan pengharapn yang didefinisikan secara social atas berbagai macam posisi social (Tuner, 2012: 79).

Adapun definisi lain mengatakan bahwa peran merupakan aspek yang dinamis dari kedudukan, artinya seseorang telah menjalankan hak-hak dan kewajibannya sesuai dengan kedudukannya. Hal tersebut telah menunjukan bahwa peran telah menentukan apa-apa yang diperbuatnya bagi masyarakat serta kesempatan apa yang diberikan masyarakat kepadanya.

Peranan-peranan social yang merupakn konsekuensi manusia dalam mengusahakan kelangsungan hidupnya dalam bermasyarakat (viabilitas) sangat ditentukan olehkonvensi-konvens dan moral suatu masyarakat, (Soekanto, 1987:221). Setiap individu dalam kehidupannya akan memiliki peran yang ditentukan baik secara langsung dengan segala aktivitas serta tanggung jawab masing-masing. Dalam hal ini, individu diharuskan melaksanakan dengan baik peranan tersebut, sehngga dapat mengatur perilaku seseorang, disamping itu peran dapat menyebabkan seseorang meramalkan perbuatan orang lain pada batas-batas tertentu sehingga seseorang dapat menyesuaikan perilakunya sendiri dengan perilaku kelompoknya.

Peran sangat penting karena dapat mengatur perilaku seseorang, disamping itu peran dapat menyebabkan seseorang meramalkan perbuatan orang lain pada batas-batas tertentu sehingga seseorang dapat menyesuaikan perlakunya sendiri dengan perilaku kelompoknya.

Istilah pemimpin adalah terjemah dari leader/head/manajer, tugasnya setiap orang yang mempunyai bawahan. Pemakaian istilah ini tergantung kepada kebiasaan atau kesenangan setiap organisasi. Jadi, hal ini tidak perlu diperdebatkan. Pemimpin merupakan salah satu sari manajemen, sumber daya pokok dan titik sentral dari setiap aktivitas yang terjadi dalam organisasi. Bagaimana kreativitas dan dinamika seorang pemimpin dalam menjalankan wewenang kepemimpinannya sangat menentukan apakah tujuan perusahaan dapat dicapai atau tidak. Pemimpin yang dinamis dan kreatif maka organisasi 
yang dipimpinnya juga akan semakin dinamis dan aktivitas yang dilakukannya akan semakin banyak.

Pemimpin adalah seseorang dengan wewenang kepemimpinannya mengarahkan bawahannya untuk mengerjakan sebagian dari pekerjaan dalam mencapai tujuan. Pemimpin adalah orang yang mengutamakan tugas, tanggung jawab dan membina hubungan yang harmonis, baik hubungan formal maupun informal (Hasibuan, 1996: 43).

Sesuai dengan tugas pemimpin yang memiliki baban yang lebih berat dari yang dipimpin maka seorang pemimpin harus memiliki kelebihan-kelebihan dalam pemikiran, daya tahan mental dan daya tahan fisik. Untuk itu menurut Yaqub pemimpin harus memiliki sejumlah sifat yang meliputi: keimanan dan ketakwan kepada tuhan yang maha esa; budi tinggi; cerdas dan berpengetahuan luas; kematangan emosi; kematangan fisik; kematangan sosial; kewibawaan; keberanian; keuletan dan kerajinan; kejujuran; adil; tanggung jawab; demokratis; antusiasme; bijaksana (Yaqub, 1984: 140).

Apabila kita perhatikan kenyataan-kenyataan di antara pemimpin yang ada, di bandingkan dengan sifat-sifat yang seharusnya di miliki oleh seorang pemimpin maka sebenarnya tidak ada seorang pun pemimpin yang memiliki sikap-sikap tersebut dengan sempurna, kecuali orang-orang yang di rahmati dan di ridhai Allah SWT, seperti para nabi dan rasul. Banyak pemimpin yang di pandang baik, tetapi masih ada juga kekurangan dan kelemahannya (Yaqub, 1984: 143).

Apabila diperhatikan cara-cara melaksanakan kepemimpinan dari berbagai pemimpin maka dapat di temukan sejumlah tipe yang merupakan gaya masingmasing pemimpin yang memancarkan sikap-sikap kepemimpinannya. Yaqub (1984:129) Tipe-tipe tersebut adalah: pemimpin yang otokratis; pemimpin yang militeristis; pemimpin yang demokratis; pemimpin yang psedou demokratis; pemimpin yang paternalistis; pemimpin yang bebas; pemimpin yang kharismatis (Nawawi, 1998: 85).

Seseorang yang menduduki jabatan pemimpin atau manajer dalam suatu organisasi memainkan peranan yang sangat penting tidak hanya secara internal bagi organisasi yang bersangkutan, akan tetapi juga dalam menghadapi berbagai pihak diluar organisasi yang semuanya di maksudkan untuk meningkatkan kemampuan organisasi dalam mencapai tujuan peran tersebut dapat di kategorikan dalam tiga bentuka, yaitu yang bersifat interpersonal, informasional dan dalam kancah pengambilan keputusan (Siagian, 2006: 66).

Kata "Pengelolaan" dapat di samakan dengan manajemen, yang berarti pula pengaturan atau pengurusan. Banyak orang yang mengartikan manajemen sebagai pengaturan, pengelolaan, dan pengadministrasian, dan memang itulah pengertian yang populer saat ini. Pengelolaan diartikan sebagai suatu rangkaian pekerjaan atau usaha yang dilakukan oleh sekelompok orang untuk melakukan 
serangkaian kerja dalam mencapai tujuan tertentu.

Manajemen bisa dikatakan juga suatu proses perencanaan dan pengambilan keputusan, pengorganisasian, memimpin dan pengendalian organisasi manusia, keuangan, fisik dan informasi sumber daya untuk mencapai tujuan organisasi secara efisiensi dan efektif. Nanang fatah berpendapat bahwa dalam proses manajemen terlibat fungsi-fungsi pokok yang ditampilkan oleh seorang manajer atau pimpinan, yaitu perencanaan (planning), pengorganisasian (organizing), pemimpin (leading), dan pengawasan (controlling). Oleh karena itu, manajemen di artikan sebagai proses merencanakan, mengorganisasikan, memimpin, dan mengendalikan upaya organisasi dengan segala aspeknya agar tujuan organisasi tercapai secara efektif dan efisien (Hasibuan, 2006: 20-21).

Istilah pesantren disebut juga dengan pondok saja atau kedua kata ini digabung menjadi istilah pesantren. Secara esensial, semua istilah ini mengandung makna yang sama kecuali sedikit perbedaan, asrama menjadi penginapan santri sehari-hari dapat dipandang sebagai pembeda antara pondok pesantren.

Secara etimologis perkataan pondok pesantren berasal dari kata "santri" dengan awalan "pe" dan akhiran "an" berarti tempat tinggal santri. Nurcholis Majid berpendapat bahwa istilah santri berasal dari perkataan "sastri" berasal dari bahasa sansekerta yang artinya "melek hirup", sedangkan Zamakhsyari Dhofier berpendapat bahwa kata santri dalam bahasa India "shastri" berarti orang yang tahu buku-buku suci agama hindu atau seseorang sarjana ahli kitab suci agama hindu (Yasmadi, 2005: 61).

Hampir dapat di pastikan lahirnya suatu pesantren berawal dari beberapa elemen dasar yang selalu ada di dalamnya. Secara garis besar pesantren memiliki lima elemen pokok, yaitu: pondok; masjid; pengajaran kitab-kitab islam klasik; santri; kiai (Dhoffer, 1982: 42).

Pesantren selain lembaga pendidikan, pesantren juga memiliki fungsi lain di antaranya sebagai berikut: a) Pesantren sebagai lembaga dakwah; b) Pesantren sebagai lembaga pengkaderan ulama, tugas ini tetap luluh dan tetap relevan pada tiap waktu dan tempat; c) Pesantren sebagai lembaga pengmbangan ilmu pengetahuan khususnya ilmu agama pada era kekinian dan era keberadaan pesantren di tengah-tengah masyarakat (Qomar, 2002: 7).

\section{HASIL DAN PEMBAHASAN}

Penelitian yang penulis lakukan berlokasi dilingkungan Pondok Pesantren AlMuhajirin Kelurahan Nagri Kaler Kecamatan Purwakarta Kabupaten Purwakarta. Alasan tempat ini sebagai lokasi penelitian adalah: Pertama, lokasi Pondok Pesantren Al-Muhajirin mudah ditempuh dengan kendaraan umum maupun kendaraan pribadi. Jarak penelitian dengan rumah peneliti kira-kira 
sepuluhu kilo meter dan juga merupakan lokasi yang dikenal peneliti, sehingga mempermudah dalam pengumpulan data dan permasalahan yang ada sesuai dengan apa yang penulis teliti; Kedua, tempat tersebut cukup representatif untuk dijadikan objek penelitian, karena peneliti ingin mengetahui sistem pengelolaan yang digunakan oleh pimpinan Pondok Pesantren Al-Muhajirin.

Di samping itu hubungan antara pihak penyusun dengan pihak pondok pesantren telah terjalin dengan baik. Kemudian dilihat dari pertimbangan kesesuaian dengan latar belakang akademik penyusun, penelitian ini tepat dilaksanakan mengingat ada korelasi antara penyusun yang sedang studi tentang manajemen dakwah dengan pengambilan judul dan objek penelitian tersebut.

Dilihat dari pertimbangan geografis, mudah dijangkau karena tempat tinggal penyusun tidak jauh dari lokasi penelitian sehingga dalam penelitian ini tidak memerlukan sarana dan prasarana yang lebih banyak.

Hasil penelitian ini menemukan tentang: Penetapan Kebijakan Program DR. KH. Abun Bunyamin, MA dan cara pengambilan keputusan pimpinan di pondok pesantren Al-Muhajirin.

\section{Penetapan Kebijakan Program DR. KH. Abun Bunyamin, MA}

Kebijakan merupakan rangkaian konsep dan asas yang menjadi pedoman dan dasar rencana dalam pelaksanaan suatu pekerjaan, kepemimpinan dan cara bertindak. Istilah ini dapat diterapkan pada pemerintah, organisasi, dan kelompok sektor swasta, serta individu. Kebijakan berbeda dengan aturan dan hokum. Jika hokum dapat memaksakan/melarang suatu perilaku (misal suatu hokum yang mengharuskan pembayaran pajak penghasilan), maka kebijakan hanya menjadi pedoman tindakan yang paling mungkin memperoleh hasil yang diinginkan.

James E. Anderson memberikan pengertian kebijakan sebagai serangkaian tindakan yang mempunyai tujuan tertentu yang diikuti dan dilaksanakan oleh seorang pelaku atau sekelompok pelaku guna memecahkan suatu masalah tertentu. Pengertian ini memberikan pemahaman bahwa kebijakan dapat berasal dari seorang pelaku atau sekelompok pelaku yang berisi serangkaian tindakan yang mempunyai tujuan tertentu. Kebijakan ini diikuti dan dilaksanakan oleh seorang pelaku atau sekelompok pelaku dalam rangka memecahkan suatu masalah tertentu. Oleh karena itu, kebijakan harus memuat 3 elemen, yaitu: a) Identifikasi dari tujuan yang ingin dicapai; b) Taktik/strategi dari berbagai langkah untuk mencapai tujuan yang diinginkan; c) Penyediaan berbagai input untuk memungkinkan pelaksanaan secara nyata dari taktik/strategi.

Dengan demikian kebijakan atau kajian kebijakan dapat pula merujuk pada proses pembuatan keputusan-keputusan penting organisasi, termasuk identifikasi berbagai alternatif seperti prioritas program atau pengeluaran dan pemilihannya 
berdasarkan dampaknya. Sehingga kebijakan juga dapat diartikan sebagai mekanisme politis, manajemen, finansial atau administratif untuk mencapai tujuan eksplisit.

Dalam menetapkan kebijakan DR. KH. Abun Bunyamin, MA senantias berpegang pada prinsip kebersamaan dalam musyawarah untuk mencapai kata mufakat. Sebab menurut beliau musyawarah merupakan prinsip dasar yang mengatur kepemimpinan Islam, Al-Qur'an menyatakan bahwa pemimpin Islam wajib mengadakan musyawarah dengan orang yang mempunyai pengetahuan atau dengan orang yang dapat memberikan pandangan yang baik.

Dalam penetapan kebijakan, terutama mengenai program beliau senantiasa mempertimbangkan beberapa hal, diantaranya: a) Tujuan utama dan fungsi keberadaan Pesantren b) Kebutuhan santri sendiri (baik untuk masa sekarang ataupun masa yang akan dating); d) Kondisi santri (kemampuan dan latar belakang Pendidikan), e) Kondisi dan sarana pesantren yang bisa mendukung.

Di pesantren Al-Muhajirin Purwakarta, musyawarah yang dilaksanakan dalam rangka penetapan kebijakan program biasanya dilaksanakan sekitar satu bulan sekali, dengan dihadiri oleh Kepala Bidang dari berbagai tingkat (PAUD, TKA, TPA, SMP, SMA, MAS) disertai para sekretaris dan seluruh jajaran dewan Guru (pengajar). Pengawasan sekaligus evaluasi untuk program itu sendiri senantiasa dilakukan dan ditinjau setiap harinya, kemudian baru pada rapat mendatang ditanyakan berhasil atau tidaknya program-program yang telah direncanakan sebelumnya.

Berdasarkan pemaparan salah satu Guru di Pesantren Al-Muhajirin Purwakarta ternyata mempunyai empat program, di antaranya: Pertama, program awal tahun ini terdiri dari penerimaan santri baru dilengkapi dengan proses seleksi (baik seleksi langsung seperti wawancara dan seleksi tulis), masa ta'aruf santri baru (MOS), pertemuan sekaligus silaturahmi dengan orang tua santri.

Kedua, program pertengahan ini terdiri dari pertemuan rutinan dengan para orang tua santri dari semua jenjang. Ketiga, program akhir tahun ini terdiri dari haflah imtihan atau acara kenaikan kelas dan riblah/study tour, haflah imtihan dan study tour itu sendiri dilaksanakan secarabergantian. Haflah imtihan merupakan acara kenaikan kelas diiringi oleh berbagai hiburan yang Islami dari para santri di masing-masing jenjangnya, sedangkan acara riblab/study tour merupakan acara kunjungan ke berbagaitempat yang dirasa ada unsur edukatif-nya.

Dengan demikian analisis terhadap penetapan kebijakan program yang dilakukan DR. KH. Abun Bunyamin, MA senantiasa mengacu pada aturan yang telah ditetapkan yaitu Al-Qur'an dan Hadits, serta senantiasa mempertimbangkan kondisi santri (kemampuan dan latar belakang pendidikan) itu sendiri sehingga dapat di sesuaikan antara program dengan metode yang akan diterapkan. 
Selain itu, dalam kebijakan program juga beliau selalu mempertimbangkan tujuan utama dan fungsi dari keberadaan pesantren itu sendiri, yang bertujuan mencetak manusia yang mempelajari, memahami dan mengerjakan amalan Islam. Juga mempertimbangkan kebutuhan santri untuk masa depan, karena tujuan dari pondok pesantren bukan hanya mendidik para santri, tapi santri juga di diharapkan dapat mengamalkan semua ilmunya baik sekarangataupun di masa yng akan dating.

Dengan demikian berarti pembuatan kebijakan khususnya mengenai program bukanlah tindakan menyalahgunakan kekuasaan atau kewenangan dan menyimpangkan peraturan/ketentuan yang berlaku untuk kepentingan pribadi atau orang tertentu. Kebijakan dimaksudkan untuk mencari jalan penyelesaian suatu masalah yang belum diatur atau aturannya belum jelas, agar diperoleh alternatif terbaik yang tidak merugikan organisasi, lembaga atau kepentingan umum.

Sebagaimana disinggung di atas bahwa salah satu program yang harus ada dalam unsur pendidikan di pondok pesantren yatu kurikulum. Kurikulum merupakan salah satu instrumen dari suatu lembaga pendidikan termasuk pendidikan pesantren. Kurikulum merupakan pengantar materi yang dianggap efektif dan efisien dalam menyampaikan misi dan pengoptimalisasian sumber daya manusia (SDM). Dalam upaya mencapai tujuan pendidikan adapun tujuan didirikannya pondok pesantren adalah mempersiapkan para santri untuk menjadi orang alim ilmu agama yang diajarkan oleh kiai yang bersangkutan serta mengamalkannya dalam masyarakat (Abdullah, 2002: 87).

Sering orang mengaitkan manajemen dengan wewenang atau kekuasaan. Tidak jarang orang berpendapat bahwa makin tinggi potensi manajerial seseorang, wewenang dan kekuasaannya pun makin besar. Wewenang atas kekuasaan itu paling sering menampakkan diri pada kekuasaan untuk mengalokasikan dana dan daya yang dimiliki organisasi (Handoko, 1984: 33).

Peranan (role) merupakan proses dinamis kedudukan (status). Apabila seseorang melaksanakan hak dan kewajiban sesuai dengan kedudukannya, dia menjalankan suatu peranan. Perbedaan antara kedudukan dengan peranan adalah untuk kepentingan ilmu pengetahuan. Keduanya tidak dapat dipisah-pisahkan karena yang satu tergantung pada yang lain dan sebaliknya. Peran merupakan pelaksanaan hak dan kewajiban seseorang sesuai dengan status sosialnya/kedudukan. Apabila seorang individu telah melaksanakan kewajibannya serta menerima hak-haknya sesuai dengan status social yang disandangnya, maka artinya ia telah melaksanakan perannya dengan tepat. Peran berasal dari pola pergaulan hidup. Oleh karena itu peran menentukan apa yang diberika masyarakat sekitarnya. Peran dianggap sangat penting karena mengatur perilaku seseorang dalam masyarakat berdasarkan norma dalam masyarakat (Soekanto, 2009: 212-213). 


\section{Cara Pengambilan Keputusan Dr. KH. Abun Bunyamin, MA}

Satu persyaratan kepemimpinan yang perlu dipenuhi oleh setiap orang yang menduduki jabatan pimpinan ialah keberanian untuk mengambil keputusan yang cepat, tepat, praktis dan rasional, serta memikul tanggung jawab atas akibat dan resiko yang timbul sebagai konsekuensi daripada keputusan yang diambilnya.

Pada hakikatnya pengambilan keputusan adalah suatu pendekatan yang sistematis terhadap suatu masalah yang dihadapi. Pendekatan yang sistematis itu menyangkut pengetahuan tentang hakikat masalah yang dihadapi, analisis masalah dengan mempergunakan fakta dan data, mencari alternatif pemecahan, menganalisis setiap alternatif sehingga ditemukan alternatif yang paling rasional, dan penilaian dari hasil yang dicapai sebagai akibat dari keputusan yang diambil.

Dalam manajemen pengambilan keputusan (decision making) memegang peranan penting karena keputusan yang diambil oleh manajer merupakan hasil pemikiran akhir yang harus dilaksanakan oleh bawahannya atau organisasi yang ia pimpin. Keputusan manajer sangat penting karena menyangkut semua aspek. Kesalahan dalam mengambil keputusan bisa merugikan organisasi, mulai dari kerugian citra sampai pada kerugian uang. Pengambilan keputusan adalah suatu proses pemikiran dalam pemecahan masalah untuk memperoleh hasil yang akan dilaksanakan.

Apapun dan bagaimanapun prosesnya, suatu tahapan lanjut yang paling sulit dihadapi pengambilan keputusan adalah dalam segi penerapannya karena disini perlu meyakinkan semua orang yang terlibat, bahwa keputusan tersebut memang merupakan pilihan terbaik. Semuanya akan merasa terlibat dan terkait kepada keputusan tersebut. Hal ini adalah proses tersulit. Walaupun demikian, bila hal tersebut dapat disadari, proses keputusan secara bertahap, sistematis, konsisten, dan dalam setiap langkah sejak awal telah mengikutsertakan semua pihak maka usaha tersebut dapat memberikan hasil yang terbaik.

Pesantren Al-Muhajirin Purwakarta merupakan lembaga yang bergerak dalam Pendidikan agama Islam, maka tidak heran jika dalam hal pengambilan keputusan memiliki kesamaan dengan lembaga lain. Proses pengambilan keputusan dalam hal ini diartikan sebagai salah satu bagian dari rangkaian proses yang mesti dilalui oleh suatu lembaga, hal ini dilakukan untuk mempertahankan perkembangan dan eksistensinya sehingga terwujud sebuah lembaga yang benarbenar dirasakan manfaatnya.

Dalam proses pengambilan keputusan biasanya akan dirumuskan menjadi sebuah kebijakan lembaga tersebut dan dilaksanakan dalam programprogram yang tersusun secara sistematis yang akan dilaksanakan secara bersamasama sesuai dengan job description (deskripsi pekerjaan) masing-masing pengurus. 
Menurut salah satu rekan kerjanya, sikap DR. KH. Abun Bunyamin, MA dalam memimpin rapat, menetapkan program sampai pada proses pengambilan keputusan, beliau senantiasa menganut asas musyawarah dan kekeluargaan, jawaban ini pun serupan dijawab DR. KH. Abun Bunyamin, MA ketika ditanya mengenai bagaimana sikap beliau dalam memimpin rapat, menetapkan program sampai pada proses pengambilan keputusan. Musyawarahlah yang paling diutamakan, sesuai dengan perintah Allah SWT dalam firman-Nya Q. S AliImran: 159, beliau tidak mengambil suara terbanyak, akan tetapi mengambil suara yang paling maslahat/terbaik.

Musyawarah itu sendiri ditujukan untuk saling bertukar pendapat dan pemikiran. Jika musyawarah berjalan dengan baik, maka para anggota rapat akan merasa termotivasi. Karena merasa dilibatkan dalam pengambilan keputusan yang berkaitan dengan lembaga. Sebenarnya, dalam musyawarah itu ada unsur penghargaan yang bersifat dari seorang pemimpin untuk menerima masukanmasukan dari para anggota. Hal ini akan berdampak positif, bahwa para anggota adalah manusia yang harus "dimanusiakan", bukan sekedar robot yang dengan seenaknya dapat diperintahkan apa saja.

Dengan adanya landasan Al-Qur'an mengenai musyawarah, surat AsySyuara:37-38 telah mengisyaratkan bahwa musyawarah merupakan salah satu sifat dan karakter orang-orang beriman. Musyawarah, apalagi yang menyangkut urusan umat, hendaknya dilakukan dengan orang yang jelas identitasnya dan berakhlak baik, agar musyawarah juga menghasilkan sesuatu yang baik pula. Allah menegaskan bahwa seandainya telah dilakukan musyawarah, maka bertakwalah kepada Allah, serta jangan lupa untuk berkomunikasi dengan Allah SWT. Dengan istikharah dan berdo'a kepada Allah agar hasil musyawarah itu dapat dilaksanakan dengan sebaik-baiknya, tutur beliau lebih lanjut.

Berdasarkan pengamatan dari pelaksanaan rapat pada tanggal 12 Juni 2017 yang membahas mengenai evaluasi program akhir tahun pembelajaran serta pembahasan kurikulum awal tahun pembelajaran, sedikitnya bisa diamati bagaimana berjalannya proses pengambilan keputusan sampai pada bagaimana penetapan kebijakan program yang dilakukan oleh DR. KH. Abun Bunyamin, MA selaku pimpinan teratas Pondok Pesantren Al-Muhajirin Purwakarta. Berikut pemaparan dari pengamatan rapat:

Proses awal, setelah para anggota rapat hadir maka pembukaan rapat diserahkan kepada sekretaris selaku Mc. Baru setelah rangkaian acara pembuka selesai, pemimpin rapat yaitu DR. KH. Abun Bunyamin, MA mulai bicara. Terkadang didalamnya mengandung berbagai unsur basa-basi yang standar, ternyata cukup penting. Sebab, di sinilah kesempatan terbesar bagi manajer/pemimpin untuk menunjukkan kebolehannya. Sistematika berpikir, kejelasan dalam berbicara, serta daya persuasive-nya dalam mengetengahkan sesuatu sebagai permasalahan yang penting, semua terlihat pada tahapan ini. 
Penampilan pada saat awal ini, baik-buruknya, bisa-bisa mewarnai sisa proses rapat bisa sampai dua jam.

Kemudian, setelah pembicaraan basa-basi tersebut dirasa cukup, maka layaknya sebuah rapat, biasanya ada tiga sampai enam menit yang tersedia bagi pimpinan rapat untuk menyampaikan hal-hal yang dirasa diperlukan untuk disampaikan, kebetulan pada waktu itu penyampaian mengenai evaluasi laporan kegiatan akhir tahun pembelajaran dan evaluasi laporan keuangan dari masingmasing jenjang dimulai dari tingkat terendah PAUD, TKA, TPA, SD Plus, SMP, SMA, dan terakhir MAS. Selain menyampaikan laporan, ada juga proses menguraikan permasalahan yang ada dari setiap jenjang.

Setelah DR. KH. Abun Bunyamin, MA selaku pimpinan rapat mengevaluasi secara umum, tinggal setiap bidang-bidang menyampaikan laporannya dari mulai program, keuangan sampai pada permasalahan. Jika ada permasalahan yang dirasa cukup rumit, maka penyelesaiannya dikembalikan pada pimpinan teratas di forum musyawarah.

Selain itu, sebagai pimpinan rapat maka tugas utamanya adalah untuk menjaga agar pembicaraan berjalan lancar. Tugas penting lainnya adalah untuk memancing pendapat dan pandangan dari para anggota rapat/musyawarah lainnya. Tentunya, sebagai pemimpin, ia tidak hanya mengatur lalu lintas pembicaraan tetapi juga ikut di dalamnya. Malah, kerap kali ucapannya dibutuhkan agar mendapatkan perspektif yang jernih dari permasalahan yang ada.

Contohnya, bidang di salah satu jenjang mengeluh kinerja dari salah seorang pengajarnya yang belum konsisten, maka setelah berbagai aspirasi ditampung, maka DR. KH. Abun Bunyamin, MA menanggapi permasalahan dan masukan dari para rekan kerjanya tersebut dan menyikapi dengan bijak sekaligus mengambil keputusan yang dirasa maslahat bagi semua pihak. Beliau berkata bahwa kondisi keluarga dari pengajar tersebut mungkin sedang kurang baik, maka solusi dari permasalahan yang ada adalah perlu adanya ketegasan dari jenjang yang menaungi pengajar tersebut.

Dari pengamatan yang ada, maka setidaknya ada beberapa hal yang perlu diperhatikan bagi seorang pemimpin rapat/musyawarah tatkala mengambil suatu keputusan, di antaranya: Pertama, kecenderungan untuk mendominasi forum pembicaraan; Kedua, kecenderungan untuk memaksakan pendapatnya melalui dominasinya terhadap peserta rapat yang notabene bawahannya itu.

Memang, demi lancar dan lurusnya pembicaraan, manajer perlu melakukan intervensi, memotong pembicaraan anggota rapatnya bila terasa tidak relevan atau menuntut penjelasan atas suatu lontaran yang kabur. Namun, ini pun hendaknya dilakukan dengan diplomatis agar tidak "memadamkan" semangat bicara mereka yang terkena intervensi.

Pembicaraan hendaknya diarahkan agar menuju pada semacam 
kesimpulan. Bila suatu kesimpulan sudah disepakati untuk suatu masalah, pindah ke hal lain untuk dibahas lebih lanjut. Kesepakatan yang tidak matang atau semu sangat berbahaya karena mempengaruhi komitmen pada saat implementasi keputusan rapat. Pihak yang merasa dipaksa setujua akan setengah hati dalam melaksanakan bagian tugasnya yang muncul dari rapat.

Rapat bisa segera diakhiri bila permasalahan-permasalahan yang ada sudah dibahas dan diperoleh kesepakatan penyelesaiannya. Demikian pula dengan tindak lanjutnya. Tinggal pimpinan sidang menegaskan kembali satu per satu kesepakatan itu dan memastikan siapa-siapa yang akan melakukan hal apa saja. Langkah selanjutnya memberi tahu hasil rapat secara detail. Kemudian akan diedarkan dan pengawasan pelaksanaan akan segera mulai. Pada tahap terakhir, tanpa banyak basa-basi, rapatpun ditutup dengan senyum pertandabahwa salah satu tugas sebagai pemimpin rapat telah dilakukan denga baik.

Dengan demikian dari hail penelitian yang telh dilakukan ditambah dengan referensi yang ada, dapat dianalisis bahwa dalam pelaksanaan pengambilan keputusan DR. KH. Abun Bunyamin, MA senantiasa menerapkan prinsip musyawarah dan kebersamaan untuk mencapai kata mufakat dengan semua elemen yang ada. Beliau selalu mempertimbangkan serta memperhitungkan dengan baik kemudian meninjau dan mengevaluasi keputusan tersebut. Proses ini dipertimbangkan kepada analisis yang dipergunakan oleh DR. KH. Abun Bunyamin, MA dengan melihat faktor-faktor yang mempengaruhunya yaitu faktor lingkungan dan sumber daya manusia (eksternal dan internal). Berdasarkan uraian-uraian di atas, maka dapat dinyatakan bahwa inti dari manajemen adalah "pengambilan keputusan", di samping pendapat lain yang menyatakan bahwa inti dari manajemen adalah "hubungan antara manusia (buman relationship)" berupa kemampuan mengkomunikasikan keputusan agar dilaksanakan.

Jikalaupun ada suatu konflik antar kelompok kerja terjadi, maka hal pertama yang beliau lakukan adalah dengan melakukan proses Tabayyun yaitu meminta penjelasan dan kejelasan dari pihak terkait mengenai permaslahan yang sedang dihadapi. Setelah diketahui kejelasannya barulah beliau mengambil stategi untuk menyelesaikan permasalahan tersebut.

Berdasarkan hasil penelitian bahwa, Pimpinan Pondok Pesantren AlMuhajirin adalah sosok pemimpin yang sangat arif dan bijaksana. Karena para staff dan mad'u yang berada di lingkungan pondok pesantren segan dengan sifat dan sikap yang dimiliki beliau. Sehingga para mad'u menerima dengan baik keberadaan beliau dan pesantren Al-Muhajirin ini.

Ketika mewawancarai keluarga, para rekan kerja, dan mad'u nya, beliau adalah sosok pemimpin yang kharismatik di zaman modern ini. Beliau sangat sederhana tetapi memiliki visi yang jauh ke depan. Sangat visioner. Kajian keilmuannya luas, namun tetap sederhana dan mudah dipahami oleh semua 
pihak.

Dari tahap pengambilan keputusan, Pimpinan Pesantren Al-Muhajirin senantiasa melaksanakan rapat atau musyawarah dalam berbagai hal sebagai media untuk saling bertukar pendapat dan pemikiran. Satu hal yang sangat menarik, dalam proses pengambilan keputusan beliau tidak mengambil suara terbanyak akan tetapi mengambil suara yang dianggap paling maslahat/terbaik dari keseluruhan pendapat yang disumbangkan oleh para anggota musyawarah dan tidak lepas dari Al-Qur'an dan Hadist.

Dalam proses penetapan kebijakan organisasi, beliau senantiasa berpegangan pada aturan yang telah ditetapkan. Selain itu beliau juga senantiasa berpegang pada asas kebersamaan dalam musyawarah untuk mencapai kata mufakat. Sedangkan, dalam proses penyusunan program beliau senantiasa mempertimbangkan tujuan utama dari fungsi keberadaan Pesantren, kebutuhan para santri (baik untuk masa sekarang ataupun masa yang akan dating), kondisi santri (latar belakang dan kemampuan), serta kondisi sarana dan prasarana yang tersedia dilingkungan Pesantren itu sendiri.

Pimpinan pondok pesantren juga berperan bukan hanya untuk memintarkan santri atau santriawati yang mondok, tapi juga mencerdaskan akhlak serta budi pekertinya terhadap orang yang lebih tua, sesama dan orang yang di bawah usianya.

Strategi yang beliau terapkan dalam proses pengembangan pesantren adalah senantiasa berpedoman pada visi dan misi kepesantrenan itu sendiri, dengan cara menyediakan berbagai program atau kegiatan unggulan dimasingmasing jenjangnya. Selain itu, ada juga kegiatan mentoring yang bekerjasama dengan para alumni Pesantren Al-Muhajirin dala rangka menggali informasi sebanyak-banyaknya tentang apa yang diinginkan para santri dari pihak pesantren. Sedangkan strategi untuk keseluruhan elemen kepesantrenan, beliau senantiasa mengedepankan faktor keteladanan, sebab keteladan memegang peranan yang sangat penting dalam mempengaruhi rekan kerjanya. Maka secara otomatis para rekan kerjanya merasa tidak terpaksa dan diperintah dalam melaksanakan setiap intruksi yang beliau utarakan.

Pimpinan Pondok Pesantren Al-Muhajirin senantiasa melaksanakan rapat atau musyawarah dalam berbagai hal sebagai media untuk saling bertukar pendapat dan pemikiran. Satu hal yang sangat menarik, dalam proses pengambilan keputusan beliau tidak mengambil suara terbanyak akan tetapi mengambil suara yang dianggap paling maslahat/terbaik dari keseluruhan pendapat yang disumbangkan oleh para anggota musyawarah dan tidak lepas dari Al-Qur'an dan Hadist.

Peran pemimpin dalam mengambil keputusan memiliki empat bentuk yaitu: Pertama, sebagai Entrepreneur seorang pemimpin di harapkan mampu 
mengkaji terus-meneus situasi yang dihadapi oleh organisasi untuk mencari dan menemukan peluang yang dapat di manfaatkan (Siagian, 2002: 68).

Kedua, sebagai peredam gangguan. Peran ini menjadikan seorang pemimpin harus bersedia memikul tanggung jawab untuk mengambil tindakan korektif apabila organisasi menghadapi gangguan yang serius yang apabila tidak ditangani akan berdampak negatif pada organisasi (Siagian, 2002: 68).

Ketiga, sebagai pembagi sumber dana dan daya. Sering orang mengaitkan manajemen dengan wewenang atau kekuasaan. Tidak jarang orang berpendapat bahwa makin tinggi potensi manajerial seseorang, wewenang dan kekuasaannya pun makin besar. Wewenang atas kekuasaan itu paling sering menampakkan diri pada kekuasaan untuk mengalokasikan dana dan daya yang dimiliki organisasi (Handoko, 2010: 33).

Keempat, sebagai perunding bagi organisasi. Telah dikemukakan bahwa makin tinggi jabatan seseorang, ia makin sering berinteraksi dengan berbagai pihak di luar organisasi. Dengan kata lain ia semakin sering berperan sebagai perunding untuk organisasi (Handoko, 1984: 33).

Seseorang yang menduduki jabatan pemimpin atau manajer dalam suatu organisasi memainkan peranan yang sangat penting tidak hanya secara internal bagi organisasi yang bersangkutan, akan tetapi juga dalam menghadapi berbagai pihak diluar organisasi yang semuanya di maksudkan untuk meningkatkan kemampuan organisasi dalam mencapai tujuan peran tersebut dapat di kategorikan dalam tiga bentuka, yaitu yang bersifat interpersonal, informasional dan dalam kancah pengambilan keputusan (Siagian, 2006: 66).

Kepemimpinan Islam adalah sebuah konsep yang tidak hanya bersifat teologis sebagai sebuah doktrin, tetapi juga sebagai kebutuhan sosial umat Islam. Kepemimpinan diyakini mampu menjadi salah satu alat untuk mencapai tujuan utama masyarakat Islam sebagaimana yang dikehendaki oleh Allah. Oleh karena itu, kepemimpinan menduduki posisi yang strategis dalam pandangan Islam (Fachrurozi, 2015: 20).

\section{PENUTUP}

Berasarkan uraian-uraian teori, hasil penelitian serta hasil analisis yang telah dilakukan, maka kiranya dapat ditarik beberapa simpulan yang diharapkan dapat mewakili uraian di atas dan sekaligus menjadi jawaban penelitian, di antaranya: Pertama, dalam penetapan kebijakan, beliau senantiasa berpegangan pada aturan yang telah ditetapkan. Selain itu beliau juga senantiasa berpegang pada asas kebersamaan dalam musyawarah untuk mencapai kata mufakat. Sedangkan, dalam proses penyusunan program beliau senantiasa mempertimbangkan tujuan utama dari fungsi keberadaan Pesantren, kebutuhan para santri (baik untuk masa sekarang ataupun masa yang akan dating), kondisi santri (latar belakang dan 
kemampuan), serta kondisi sarana dan prasarana yang tersedia dilingkungan Pesantren itu sendiri.

Kedua, dalam tahap pengambilan keputusan, Pimpinan Pondok Pesantren AlMuhajirin senantiasa melaksanakan rapat atau musyawarah dalam berbagai hal sebagai media untuk saling bertukar pendapat dan pemikiran. Satu hal yang sangat menarik, dalam proses pengambilan keputusan beliau tidak mengambil suara terbanyak akan tetapi mengambil suara yang dianggap paling maslahat/terbaik dari keseluruhan pendapat yang disumbangkan oleh para anggota musyawarah dan tidak lepas dari Al-Qur'an dan Hadist.

Ketiga, Pimpinan Pondok Pesantren Al-Muhajirin adalah sosok pemimpin yang sangat arif dan bijaksana. Karena para staff dan mad'u yang berada di lingkungan pondok pesantren segan dengan sifat dan sikap yang dimiliki beliau. Sehingga para mad'u menerima dengan baik keberadaan beliau dan pesantren Al-Muhajirin ini.

Keempat, Dari tahap pengambilan keputusan, Pimpinan Pesantren Al-Muhajirin senantiasa melaksanakan rapat atau musyawarah dalam berbagai hal sebagai media untuk saling bertukar pendapat dan pemikiran. Satu hal yang sangat menarik, dalam proses pengambilan keputusan beliau tidak mengambil suara terbanyak akan tetapi mengambil suara yang dianggap paling maslahat/terbaik dari keseluruhan pendapat yang disumbangkan oleh para anggota musyawarah dan tidak lepas dari Al-Qur'an dan Hadist.

Sehubungan telah selesainya penulisan skripsi ini, ada beberapa rekomendasi yang bisa dilaksanakan oleh Pondok Pesantren Al-Muhajirin Jalan Veteran No 155 Kelurahan Nagri Kaler Kecamatan Purwakarta Kabupaten Purwakarta khususnya oleh Pimpinan Pesantren Al-Muhajirin selaku pimpinan teratas dilembaga pesantren tersebut, diantaranya:

Untuk mengantisipasi tantangan kedepan perlu adanya standarisasi dan pembinaan pesantren kearah yang lebih baik. Standarisasi tersebut dapat mengacu pada pengelolaan pesantren berdasarkan manajemen modern yang diantaranya dengan alat ukur SWOT. Analisis SWOT ini sangat diperlukan dalam menilai potensi didalam (kekuatan dan kelemahan yang dimiliki) dan potensi luar (tantangan dan ancaman) pesantren itu sendiri.

Pesantren diharapkan terbuka menerima perkembangan ilmu pengetahuan yang semakin hari semakin meningkat, akan tetapi tetap mempertahankan ciri dari kekhasan pesantren itu sendiri serta yang paling utama mampu mempertahankan nilai-nilai islam.

Bagi pengelola dan juga pemerintahan untuk selalu memberikan pemahaman kepada masyarakat yang luas perihal tentang bagaimana menjalani hidup baik yang berkenaan dengan pendidikan agama serta dalam mendidik anak supaya mencintai Islam dan mengenal pencipatanya melalui pondok pesanteren. 
Mempertahankan hubungan yang harmonis dan meningkatkan kualitas pada pengajar sehingga terciptanya kerjasama yang baik dengan semua pihak.

\section{DAFTAR PUSTAKA}

Fachrurozi, M. (2015). Trilogi Kepemimpinan Islam: Analisis Teoritik terhadap Konsep Khilafah, Imamah dan Imarah. Ilmu Dakwah: Academic Journal for Homiletic Studies, 4(12), 289-304.

Yaqub, H. (1998). Etika Islam Pembinaan Akblakul Karimah (Suatu Pengantar), Bandung: CV. Diponegoro

Handoko, H. (2010). Manajemen Personalia dan Sumberdaya Manusia, Edisi kedua, Jogjakarta: BPFE UGM.

Hasibuan, M.S.P. (2000). Organisasi Kepemimpinan dan Perilaku Administrasi, Jakarta: P. T. Toko Agung.

Hasibuan, M.S.P. (1996). Manajemen Dasar, Pengertian dan Masalah , Jakarta: PT. Gunung Agung

Nawawi, H. (1998). Manajemen Sumber Daya Manusia. Yogyakarta: Gadjah Mada, University Press.

Siagian, S. P. (2004). Filsafat Administrasi, Jakarta: Bumi Aksara.

Schrorff, V. D. dan Makaliwe, W. (1985). Manajemen dan Organisasi Perusahaan, Jakarta: Ghalia Indonesia.

Soekanto, S. (2009). Peranan Sosiologi Suatu Pengantar, Edisi Baru Jakarta: Rajawali Pers. 